\title{
A Budai Arborétum mohaflórája
}

\author{
RIGÓ Attila ${ }^{1}$, KOVÁCS Andor ${ }^{2}$ és NÉMETH Csaba ${ }^{3}$ \\ ${ }^{1}$ Magyar Természettudományi Múzeum Növénytár, \\ 1087 Budapest, Könyves Kálmán krt.40.; rigo.attila@nhmus.hu \\ ${ }^{2}$ Szent István Egyetem, Kertészettudományi Kar, 1118 Budapest, Villányi út 29-43. \\ ${ }^{3}$ MTA Ökológiai Kutatóközpont, GINOP Fenntartható Ökoszisztémák Csoport, \\ 8237 Tihany, Klebelsberg Kuno út 3.
}

Elfogadva: 2019. május 29.

Kulcsszavak: életstratégiák, gyüjteményes kertek, mohaflorisztika, ökológiai jelzőszámok.

Összefoglalás: A Budai Arborétum teljes területét lefedő mohaflorisztikai kutatást végeztünk, melynek eredményeként összesen 56 mohafajt (4 májmohát és 52 lombosmohát) észleltünk. Főként országosan gyakori fajok kerültek elő a kutatás során, azonban a Vörös Listán mérsékelten fenyegetett (NT) kategóriába sorolt 4 faj (Gymnostomum calcareum, Orthotrichum obtusifolium, Orthotrichum pumilum, Pseudocrossidium revolutum) előfordulása figyelemre méltó. Fakérgen az Orthotrichum diaphanum, sziklán a Schistidium crassipilum, betonon az Amblystegium serpens van jelen legnagyobb borítással, talajon az Eurhynchium hians a leggyakoribb. A kertben élö mohafajok majd háromnegyede a hőklímához való alkalmazkodás (T-érték) szempontjából a „lomblevelü” hőháztartás típushoz tartozik. A környezeti nedvességhez való alkalmazkodottság (W-érték) szempontjából az „extrém száraz”, „igen száraz”, „száraz”, „mérsékelten száraz” csoportokba tartozik a fajok majd kétharmada, ez jól mutatja a kert száraz klímáját. Az aljzat $\mathrm{pH}$-jához való alkalmazkodottság (R-érték) alapján a fajok közel fele-fele arányban az indifferens, illetve a bázikus indikációval jellemezhető csoportokba tartoznak. Életstratégia szempontjából a fajok közel kétharmada pionír természetủ, kolonista (C), a többi faj évelő állandó (P), hosszú életű vándorló (LS), rövid életű vándorló, átfutó (F), illetve egyéves vándorló (AS).

\section{Bevezetés}

Az ország területén fellelhető arborétumok és botanikus kertek értékei közé tartoznak a kriptogám növények is. A gyüjteményes kertek edényes növényanyaga tudatos telepítés eredményeként áll össze, a kertek moha- és zuzmó életközösségei viszont döntő többségben spontán módon szerveződnek. A gyűjteményes kertek mohaflórájának felmérésére az 1930-as évektől kezdődően napjainkig találunk példákat. Boros (1915-1971) útinaplóiban 1933-tól kezdve találhatunk elszórt mohaflorisztikai adatokat Kárpát-medencei arborétumok és botanikus kertek területéről. IGMÁNDY (1949) szórványos adatokat közölt a Soproni Botanikus Kert területéről. Vajda László már kifejezetten gyüjteményes kertek mohaflóráját feldolgozó müveiben a Vácrátóti Botanikus Kert (VAJDA 1954) és 
a Szigligeti Arborétum (VAJDA 1968) mohafajait összegezte. Hosszabb szünet után újabb gyüjteményes kertek mohaflórája került részletes feltárásra, ezek a következők: Zirci Arborétum (Galambos 1992), melyhez később Szűcs (2013) füzött kiegészítéseket, Agostyáni Arborétum (Tata) (SzŰCs 2009), Soroksári Botanikus Kert (NÉMETh és PAPp 2016), Eszterházy Károly Egyetem Botanikus Kertje (Eger) (SZŰCs és PÉnZEsné KónYa 2016, SzŰcs et al. 2017c), Erdőtelki Arborétum (Szűcs et al. 2017a), Soproni Botanikus Kert (Szücs 2017). A gyüjteményes kertek mellett a Martonvásári Kastélypark (NAGY et al. 2016), illetve Almásfüzitő (Szücs és Lóth 2008, Szücs et al. 2017b) és Balaton (ZsóLYom és SzŰcs 2018) települések, valamint a Mátrai Állami Gyógyintézet (Gyöngyös) kertje (Szücs et al. 2018) mohaflórájának feldolgozása is megtörtént. Ezen kutatások az általánosan elterjedt fajok kimutatása mellett unikalitásokkal is szolgáltak, pl. a Vácrátóti Botanikus Kert felmérése során került elő az Entodon concinnus (De Not.) Par., amely azóta is a faj egyetlen ismert hazai előfordulása (VAjDa 1954, Pócs et al. 2008).

\section{Anyag és módszer}

A terepi munkát 2015-ben és 2016-ban végeztük. A felmérés során SCHMIDT (2013) térképét használtuk, valamennyi fás szárú növényt, valamint minden épületet és talajfelszínt teljes felületén megvizsgáltunk. A terepi felmérés több mint 30 napot vett igénybe, minden évszakban átnéztük a területet. A mohák meghatározásához SMITH (2004) és ERzBERGER (előkészületben) kulcsait használtuk. A mohafajok nevezéktana, valamint vörös listás besorolásuk PAPP és mtsai. (2010) munkáját követi, ám kivételt tettünk a Syntrichia nemzetség fajai esetében, ezek nevezéktanánál HiLl és mtsai. (2006) munkájára támaszkodtunk. A mohafajok hazai elterjedésének ismertetése során BOROs (1953), illetve ORBÁN és VAJDA (1983) munkáira támaszkodtunk. Az Enumeráció fejezetben a mohafajok nevei után feltüntettük azok IUCN Vörös Listás kategóriáját, az itt használt szabványos rövidítések a következőket jelentik: LC (least concern) $=$ nem fenyegetett; LC-att (least concern attention) = nem fenyegetett, de megfigyelést igényel (ezt az alkategóriát PAPP és mtsai. (2010) használták a magyar moha vörös lista összeállításakor); NT (near threatened) = mérsékelten fenyegetett. A mohák ökológiai jelzőszámok (TWR-értékek) és stratégia típusok szerinti besorolása ORBÁN (1984) munkája alapján történt. A fakérgen, sziklán és betonon elöforduló mohafajokról borítási becslést végeztünk, a talajon élő fajok borítási viszonyainak felmérésétől a különféle zavaró tényezők (kaszálás, taposás, új telepítések stb.) függvényében fellépő erőteljes fluktuáció miatt eltekintettünk. A becslés során tárgyi eszközöket nem használtunk, a kapott adatok nem tekinthetők pontosnak, csak egy hozzávetőleges képet adnak az arborétumban található fa- 
jok borítási arányairól. Az Orthotrichum pumilum Sw. és az O. pallens Bruch ex Brid. megbízható elkülönítése csak mikroszkópos vizsgálattal lehetséges, ezért a terepen végzett becslés során az említett két fajt együtt kezeltük.

\section{Kutatási terület}

A Budai Arborétum (1. ábra) a Villányi út, a Szüret utca és a Somlói út által határolva a főváros szívében, a Budai-hegység délkeleti szélén, a Gellért-hegy déli lábánál, városi környezetben helyezkedik el. Az arborétum két külön kertrészből (Alsó és Felső Kert) áll, melyeket a Ménesi út választ el egymástól. 1975 óta természetvédelmi terület, jelenleg a Szent István Egyetem kezelésében áll. Az arborétum 9 hektáron terül el, ebből 7,5 hektár a növényekkel borított felület, a fennmaradó 1,5 hektáron épületek, illetve burkolt utak, terek találhatók. A város hatásának és a terület déli kitettségének köszönhetően az arborétum klímája meleg és száraz, az éves csapadékmennyiség $600 \mathrm{~mm}$ körül alakul. A terület alapkőzete mészkő és dolomit, melyre agyag és budai márga rakódott, ezeken kötött, meszes talajok jöttek létre (SCHMIDT 2013). Az arborétumban több mint 1900 fás szárú növény él, a déli fekvésnek, a sajátos mikroklímának, valamint a tudatosan kivitelezett növénytelepítéseknek köszönhetően olyan fafajok is megtalálhatóak itt, melyek az ország más részein a téli fagyokat nem élnék túl (SCHMIDT 2013). A területen több sziklakert, különálló szikla- és betonépítmény, valamint egy kerti tó is található.

\section{Eredmények}

\section{Enumeráció}

\section{Telepes májmohák}

Pellia endiviifolia (Dicks.) Dumort. - LC - Nedves, vizes élőhelyeken, patakpartokon, hegy- és dombvidékeinken egész Magyarországon gyakori faj. Az arborétumban csak a kerti tó partján, egyetlen, tenyérnyi foltban nő.

Marchantia polymorpha L. - LC - Országosan gyakori, nedves, árnyas helyeken, árkokban, falak tövében élő, pionír természetű faj. Az arborétumban egyetlen helyen, az „F” épület északi falánál húzódó, árnyékos, nyirkos, kavicsos talajon található egy néhány négyzetméteres, összefüggő állománya.

\section{Leveles májmohák}

Frullania dilatata (L.) Dumort. - LC - Széles körben elterjedt, az egész országban gyakori faj. Félárnyékos, árnyékos fatörzseken, sziklákon nő. Az arbo- 
Rigó A. et al.

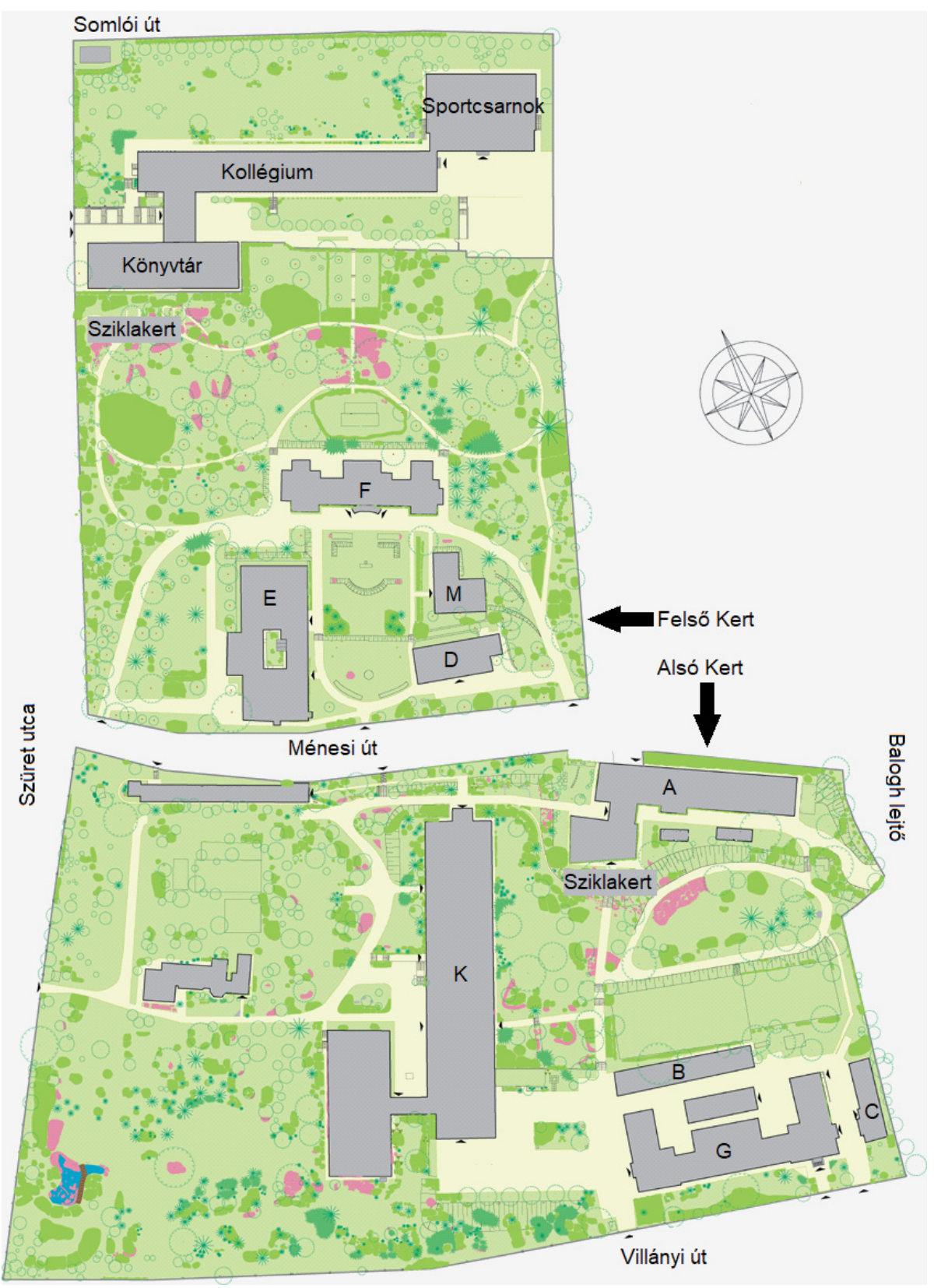

1. ábra. A Budai Arborétum térképe (forrás: http://budaicampus.szie.hu/hu/szervezeti-egysegek, módosította: Rigó Attila).

Fig. 1. Map of the Buda Arboretum (source: http://budaicampus.szie.hu/hu/szervezeti-egysegek, modified by Attila Rigó). 
rétumban igen ritka, csak a Felső Kert néhány fáján fordul elő, pl. az „M” épület melletti Diospyros lotus L. törzséről került elő.

Radula complanata (L.) Dumort. - LC - Epifiton, félárnyékos, üdébb élőhelyeket kedvelö, gyakori mohafaj. Az arborétumban ritka, csak a Felső Kert idősebb tölgyeinek kérgén észleltük.

\section{Lombosmohák}

Amblystegium humile (P. Beauv.) Crundw. - LC - Nedves élőhelyek indikátora, megtalálható források, patakok környékén, sziklákon, fakérgen, talajon egyaránt. Antropogén környezetben az üvegházak páradús környezetében, virágcserepekben egyaránt találkozhatunk vele. Az arborétumban egyetlen helyen, a „K” épület melletti üvegházban, virágcserépben találtuk.

Amblystegium serpens (Hedw.) Schimp. - LC - Félárnyékos, árnyékos élőhelyeken, talajon, fák kérgén, sziklákon, betonon előforduló, természetes és antropogén környezetben egyaránt gyakori mohafaj. Fák kérgén, északi fekvésű, árnyas beton építményeken és sziklákon gyakori az arborétumban.

Anomodon viticulosus (Hedw.) Hook. et Taylor - LC - Félárnyékos, árnyékos, jellemzően vertikális helyzetü bázikus sziklákon, fatörzseken az egész országban gyakori. Az arborétumban kizárólag a Felső Kert alsó részén találtuk Fraxinus excelsior L. törzsén.

Barbula convoluta Hedw. - LC - Zavart, nyílt élőhelyeken, kertekben, talajfelszínen, utak mentén, falak repedéseiben felhalmozódott humuszanyagon országszerte gyakori. Az arborétumban nyílt talajfelszíneken szórványos.

Barbula unguiculata Hedw. - LC - Meszes aljzatokon országosan elterjedt faj. Gyakran antropogén környezetben is megtalálható nyílt talajfelszínen, betonrepedésekben, utak mentén, agyagos, löszös talajokon. Az arborétumban mindenütt gyakori, utak mentén, útrepedésekben, füves területeken, nyílt talajfelszínen és sziklák közt egyaránt.

Brachythecium rutabulum (Hedw.) Schimp. - LC - Igen gyakori az egész országban, sziklákon, betonon, füves területeken, fatörzsön egyaránt előfordul. Az arborétum árnyékos, nyirkos, füves területein jellemzően megtalálható, ritkábban napsütötte sziklafelszíneken, fák gyökereinek talajfelszíni kibukkanásain is megjelenik.

Brachythecium salebrosum (Hoffm. ex F. Weber et D. Mohr) Schimp. - LC Nedves, nyirkos helyeken, fák törzsén, korhadó faanyagon, sziklákon, talajon az országban mindenfelé előfordul. Az arborétumban nem gyakori, kis állományai a felső sziklakertben, továbbá az „A” épület nyugati felén beton- és talajfelszínen találhatók. 
Bryum argenteum Hedw. - LC - Országszerte széles körben elterjedt, közönséges, nitrofil faj. Általánosan elöfordul ember által készített építményeken, betonon, aszfalton, tetőkön, üvegházakban, de nyílt talajfelszíneken is gyakori. $\mathrm{Az}$ arborétum területén is közönséges faj, mindenféle aljzaton.

Bryum bicolor Dicks. - LC - Hazánkban gyakori talajlakó moha, az arborétumban betonkerítések tövében, valamint a felső sziklakertben, talajon él kis mennyiségben.

Bryum capillare Hedw. - LC - Országosan elterjedt, gyakori faj. Főleg talajon, utak mellett, de falakon, sziklákon, ritkábban fatörzseken is előfordul. Az arborétumban ritka, a Felső Kertben fák tövében találhatók kisebb párnái.

Bryum moravicum Podp. - LC - Országszerte gyakori, leggyakrabban fatörzseken, korhadó fákon élő faj. Az arborétum területén élő fák kérgén szintén elterjedt.

Calliergonella cuspidata (Hedw.) Loeske - LC - Hegy- és dombvidékeink nedves, vizes élőhelyein, sásréteken, árkokban, nedves ligetekben gyakori faj, de ritkán szárazabb erdőszéleken is előfordul. Az arborétumban csak a kollégium fölötti területről, cserjék, kúszónövények által árnyékolt, tartósan üde talajról került elö.

Ceratodon purpureus (Hedw.) Brid. - LC - Az ország egész területén gyakori mészben szegény, kilúgozott helyeken, falakon, talajon, betonfelületeken. Az arborétumban szintén gyakori, főleg betonkerítéseken fordul elö.

Dicranella varia (Hedw.) Schimp. - LC - Árnyas, nyirkos, bázikus talajon, agyagon, homokon él. Hazánkban gyakori utak mentén, kavicsos talajon. Az arborétumban csak a kerti tó partján, illetve az „F” épület északi oldalán találtuk meg.

Didymodon fallax (Hedw.) R. H. Zander - LC - Bázikus talajon és mésztartalmú sziklákon az egész országban gyakori. Az arborétumban csak a felső sziklakertben leltük egy kisebb populációját.

Didymodon luridus Hornsch. - LC - Általánosan előfordul bázikus sziklákon, falakon, betonon, árnyas és kitett helyeken egyaránt. Országszerte gyakori faj. Az arborétumban csak a felső sziklakertben él.

Didymodon rigidulus Hedw. - LC - Mészkősziklák, löszfalak indikátora, antropogén környezetben betonon, falakon is megtalálható. Országszerte gyakori. Az arborétumban bázikus sziklákon és betonfelületen találtuk meg. Nagy területet borít a kollégium északi oldalán található lépcsőn.

Encalypta streptocarpa Hedw. - LC - Mésztartalmú sziklák repedéseiben, árnyas, nyirkos, védett helyeken él, középhegységeinkben gyakori. Az arborétumban csak a kollégium északi lépcsőin, függőleges felületen, Didymodon rigidulus-szal együtt található. 
Eurhynchium hians (Hedw.) Sande Lac. - LC - Az országban mindenhol megtalálható nedves, semleges vagy bázikus talajfelszínen, füves területeken, sziklákon, falakon. Az arborétumban nagy területeket borít a füves részeken, a kert területén az egyik leggyakoribb faj.

Fissidens gracilifolius Brugg.-Nann. et Nyholm - LC-att - Hazánkban gyakori faj, bázikus sziklákon él. Az arborétumban igen ritka, kizárólag a felső sziklakertből került elö.

Fissidens taxifolius Hedw. - LC - Hazánkban gyakori, föként árnyékos, félárnyékos talajon, művelt területeken, füvesített helyeken fordul elö. Az arborétumban árnyékos talajfelszíneken gyakori faj.

Funaria hygrometrica Hedw. - LC - Országszerte gyakori faj, főként antropogén hatásoknak kitett helyeken él. Az arborétum betonkerítéseinek tövében elszórtan fordul elö.

Grimmia dissimulata E. Maier - LC - Országosan gyakori moha, napos mészkő- és dolomitsziklákon él. Az arborétumban ritka, a felső sziklakert meszes szikláin találtuk meg.

Grimmia pulvinata (Hedw.) Sm. - LC - Igen gyakori az egész országban. Kitett helyeken, napos, bázikus sziklákon, antropogén környezetben falakon, betonfelületeken egyaránt előfordul. Az arborétumban is gyakori, főleg a betonfelületeken és a sziklakertekben fordul elő.

Gymnostomum calcareum Nees et Hornsch. - NT - Meszes alapkőzeten gyakori faj, sziklák repedéseiben, árnyékos helyeken él. Az arborétumban igen ritka, a felső sziklakertből került elő egy kisebb állománya.

Homalothecium sericeum (Hedw.) Schimp. - LC - Az egész országban megtalálható, föleg napos, kitett helyeken, sziklákon, falakon, de fakérgen is megjelenik. Az arborétumban kis borításban, föleg a felső sziklakertben és betonfelületeken él.

Hypnum cupressiforme Hedw. - LC - Országosan gyakori faj, fakérgen, sziklán, betonfelületeken, talajon egyaránt megtalálható. $\mathrm{Az}$ arborétum területén is gyakori, fakérgen, betonon él.

Leptobryum pyriforme (Hedw.) Wilson - LC - Országosan nem ritka faj, antropogén környezetben különösen üvegházakban, virágcserepekben, agroszöveten. Az arborétumban egyetlen helyen, a „K” épület melletti üvegházban, virágcserépben találtuk.

Leskea polycarpa Ehrh. ex Hedw. - LC - Az egész országban gyakori, ártereken, erdőkben, parkokban mindenütt megtelepedik. Fakérgen, ritkábban sziklákon él. Az arborétumban fák kérgén gyakori.

Orthotrichum affine Schrad. ex Brid. - LC - Kéreglakó, de ritkán sziklákon is előfordul, az egész országban elterjedt. Az arborétumban ritka, néhány idősebb fa kérgén nő pl. a „K” épület melletti Acer pseudoplatanus L. kérgén. 
Orthotrichum anomalum Hedw. - LC - Meszes sziklákon, falakon, az egész országban gyakori. Az arborétumban nagy tömegben a kert betonkerítésén, a felső sziklakert szikláin, valamint a Felső Kert betonépítményein nő.

Orthotrichum cupulatum Brid. - LC - Mészkö- és dolomitsziklákon a hegyvidéki területeinken általánosan elterjedt faj. Az arborétumban a felső sziklakert árnyasabb szikláin fordul elö.

Orthotrichum diaphanum Schrad. ex Brid. - LC - Elsősorban fakérgen, de sziklákon is előfordul, az egész országban gyakori. Az arborétum leggyakoribb kéreglakó mohája, de különféle betonfelületeken is elterjedt.

Orthotrichum lyellii Hook. et Taylor - LC - Kéreglakó, főleg szárazabb erdőkben, idős fák kérgén él. Az egész országban elterjedt, de nem gyakori. Az arborétumban kizárólag a Felső Kertben, Fraxinus americana L. törzséről került elő igen kis mennyiségben.

Orthotrichum obtusifolium Brid. - NT - Magyarországon elterjedt epifiton moha. Az arborétum idősebb fáin gyakori, néhol nagy borítással fordul elő.

Orthotrichum pallens Bruch ex Brid. - LC - Országosan gyakori epifiton moha. Az arborétumban is megtalálható különféle fák kérgén.

Orthotrichum pumilum Sw. - NT - Országosan elterjedt kéreglakó moha. $\mathrm{Az}$ arborétumban is megtalálható különféle fák kérgén.

Orthotrichum speciosum Nees - LC-att - Hazánkban gyakori epifiton moha, az arborétumban kevés fáról került elő, javarészt a Felső Kertben található, pl. Quercus libani G. Olivier kérgén.

Orthotrichum striatum Hedw. - LC-att - Kéreglakó, országosan elterjedt faj. Egyetlen előfordulása ismert az arborétumban, a Felső Kertben az „F” épület melletti Populus $\times$ canescens (Aiton) Sm. kérgén nő.

Plagiomnium cuspidatum (Hedw.) T. J. Kop. - LC - Nedves, árnyékos, bázikus talajon, esetenként fakérgen vagy sziklákon él, főleg síkvidéki, dombvidéki faj, erdőkben, parkokban mindenütt gyakori. Az arborétumban néhány viszonylag nagy kiterjedésű foltot alkot.

Phascum cuspidatum Hedw. - LC - Gyakori és elterjedt talajlakó mohánk, főként száraz élőhelyeken fordul elő. Az arborétumban a sziklakertekben, illetve a betonkerítések tövében nő.

Pottia lanceolata (Hedw.) Müll. Hal. - LC-att - Hazánkban gyakori, pionír talajlakó moha. Az arborétumban aszfaltutak repedéseiben, valamint betonkerítések tövében, nyílt talajfelszínen nő.

Pseudocrossidium hornschuchianum (Schultz) R. H. Zander - LC - Gyakori talaj- és sziklalakó moha, füves területeken, kőtörmeléken, meszes sziklákon, kitett helyeken él. Mesterséges aljzatokon, utak mentén, falakon is elöfordulhat. Az arborétumban nyíltabb talajfelszíneken mérsékelten gyakori. 
Pseudocrossidium revolutum (Brid.) R. H. Zander - NT - Mészkedvelő faj, sziklákon, köves talajon, de mesterséges építményeken is előfordul. Magyarországon mérsékelten gyakori. Az arborétum területéről a felső sziklakertből került elö kis mennyiségben.

Pylaisia polyantha (Hedw.) Schimp. - LC - Kéreglakó, főként nyíltabb erdőkben él, Magyarországon gyakori. Az arborétum területén is elterjedt, főleg idősebb fák kérgén fordul elő.

Schistidium crassipilum H. H. Blom - LC - Gyakori faj, mésztartalmú sziklákon, de mesterséges aljzaton is előfordul, pl. falakon, betonon. Az arborétum sziklakertjeiben, kőfalain és betonépítményein is elterjedt.

Syntrichia montana Nees - LC-att - Kitett, napos sziklákon él, mérsékelten gyakori. Az arborétum felső sziklakertjében csekély mennyiségben fordul elő.

Syntrichia papillosa (Wilson) Jur.- LC-att - Elsősorban epifiton, de nagyon ritkán sziklákon is nő. Magyarországon mérsékelten gyakori. Az arborétum fáin elterjedt és gyakori faj.

Syntrichia ruralis (Hedw.) F. Weber et D. Mohr - LC - Meszes és szilikátos sziklákon, talajon, fakérgen, háztetőkön az országban mindenfelé elterjedt és gyakori faj. Az arborétumban mérsékelten gyakori, mindenféle aljzaton elöfordul.

Syntrichia virescens (De Not.) Ochyra - LC-att - Magyarországon gyakori faj, főleg fakérgen, ritkán sziklákon nő. Az arborétum fáin elterjedt, mérsékelten gyakori moha.

Tortula muralis Hedw. - LC - Falakon, betonon, sziklákon országosan gyakori. Az arborétumban a sziklakertekben és a mesterséges építményeken tömeges, de esetenként fakérgen is megtalálható. Az arborétum egyik leggyakoribb mohafaja.

Tortella tortuosa (Hedw.) Limpr. - LC - Hegyvidékeinken árnyas, félárnyékos sziklákon és sziklarepedésekben gyakori. Az arborétumban a felső sziklakertben találtuk kis borítással.

\section{Megvitatás}

Az arborétum leggyakoribb epifiton mohafaja az Orthotrichum diaphanum, legritkábbak az Anomodon viticulosus, az Orthotrichum affine, az Orthotrichum lyellii és a Radula complanata (2. ábra). Mészkősziklákon legnagyobb borítással a Schistidium crassipilum, míg legkisebb borítással a Fissidens gracilifolius, a Gymnostomum calcareum és a Syntrichia ruralis van jelen (3. ábra). Betonfelületeken az Amblystegium serpens a leggyakoribb és a Pseudocrossidium hornschuchianum a legritkább (4. ábra). 


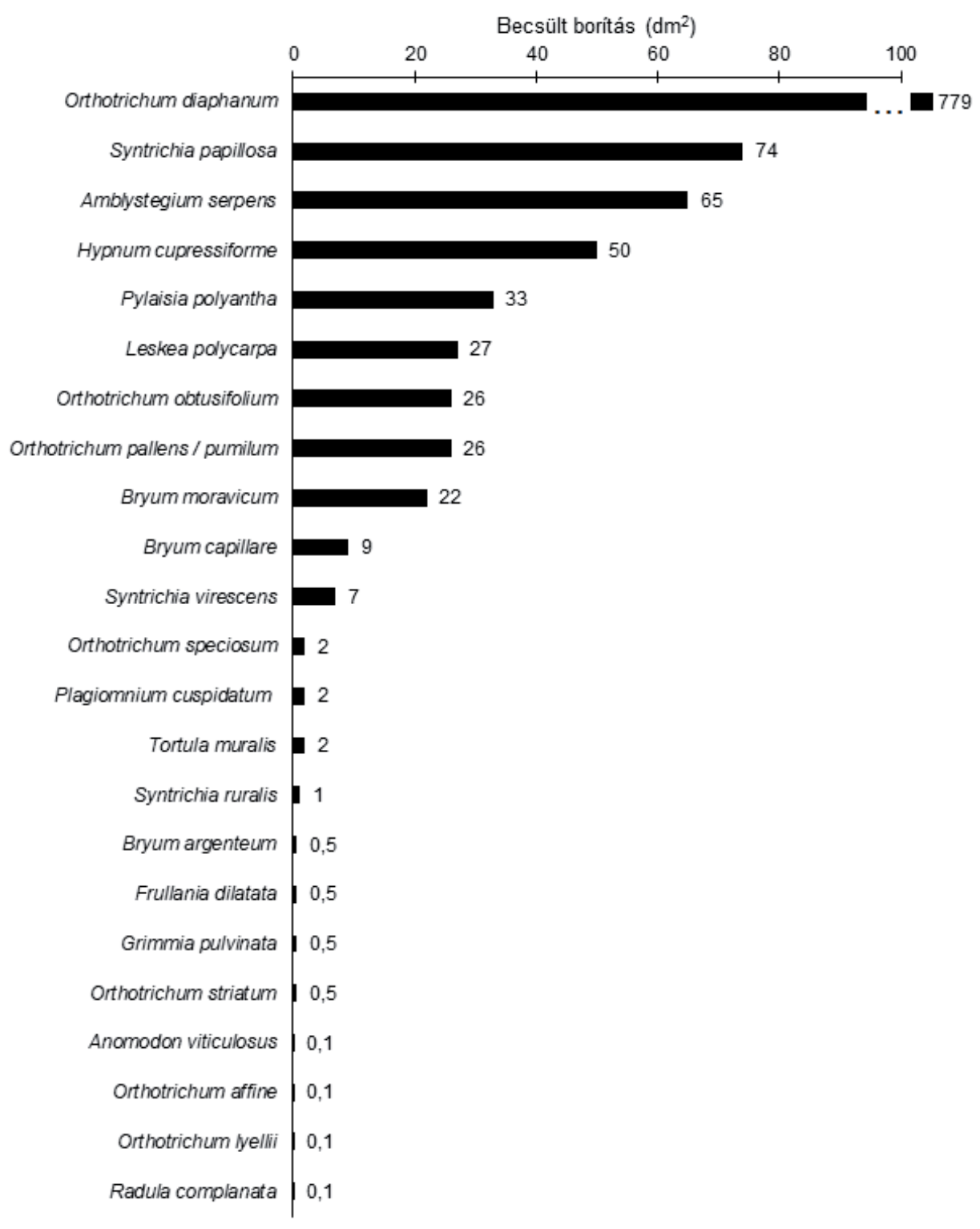

2. ábra. A Budai Arborétum kéreglakó moháinak becsült borítási értékei.

Fig. 2. Estimated cover values $\left(\mathrm{dm}^{2}\right)$ of epiphytic bryophytes in the Buda Arboretum. 


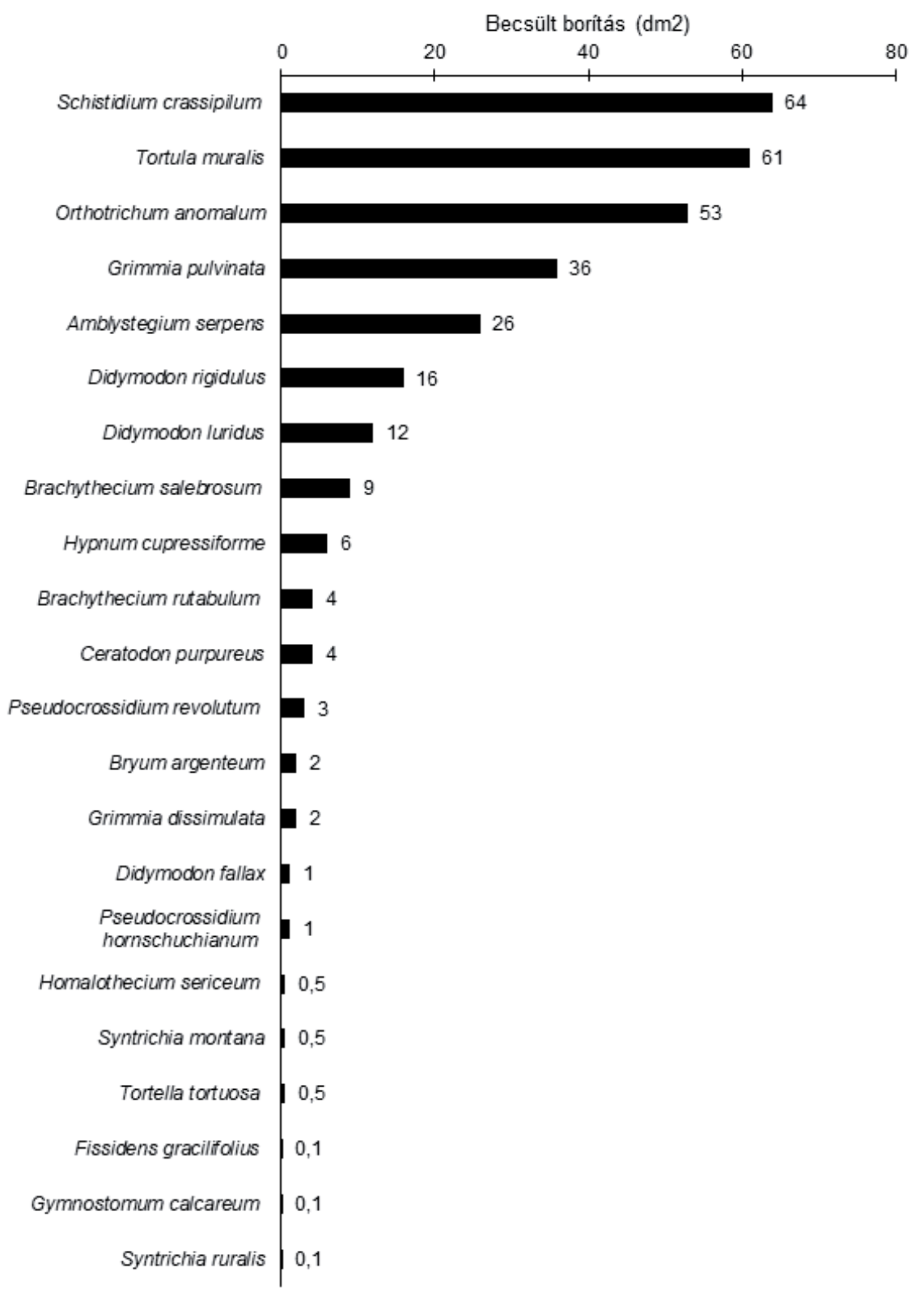

3. ábra. A Budai Arborétum sziklalakó moháinak becsült borítási értékei.

Fig. 3. Estimated cover values $\left(\mathrm{dm}^{2}\right)$ of bryophytes growing on rocks in the Buda Arboretum. 
Rigó A. et al.

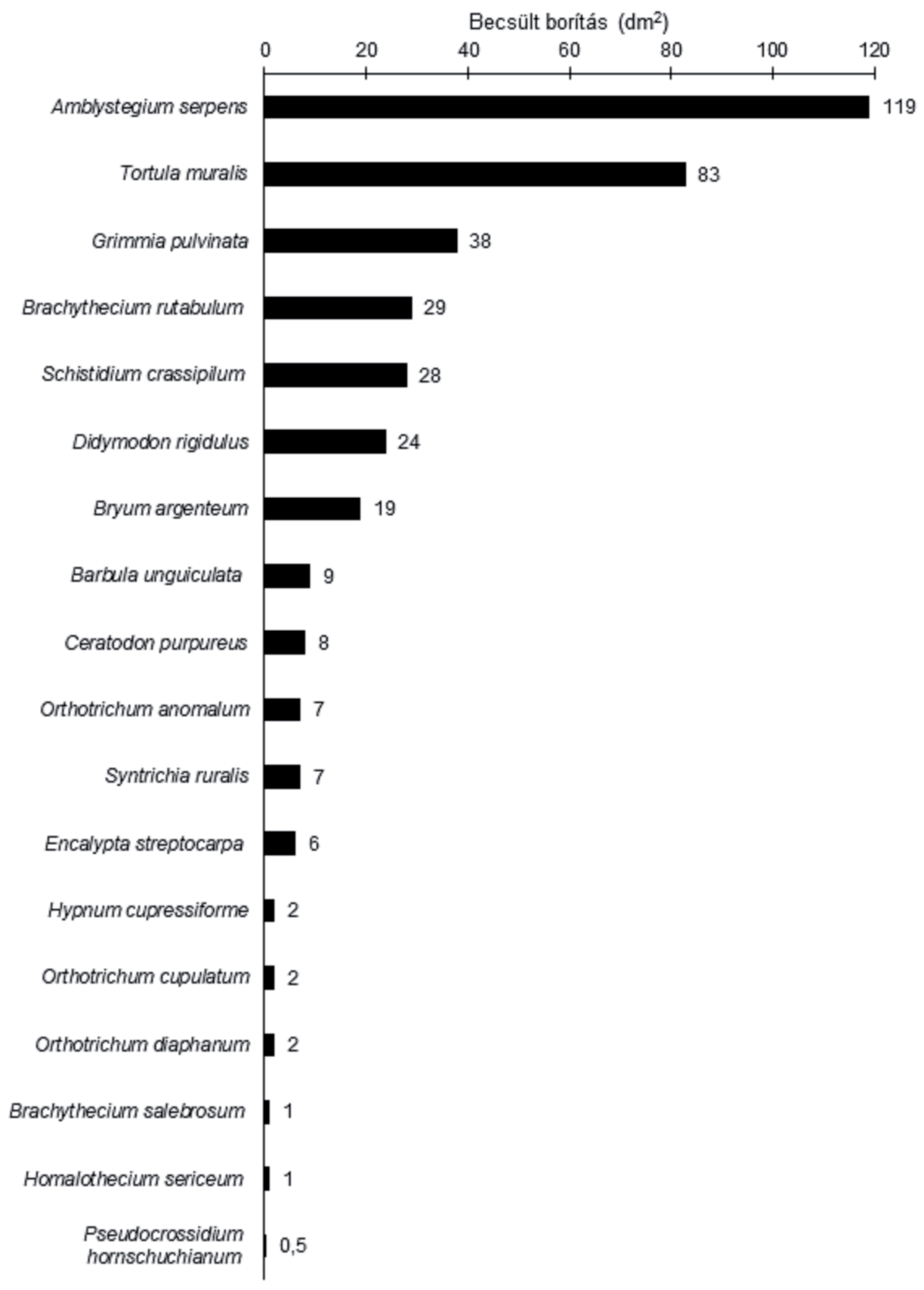

4. ábra. A Budai Arborétum betonon növő moháinak becsült borítási értékei.

Fig. 4. Estimated cover values $\left(\mathrm{dm}^{2}\right)$ of bryophytes growing on concrete in the Buda Arboretum. 
A kertben előforduló mohafajok döntő többsége (73\%, 41 faj) a hőigény (T-érték) szempontjából a „lomblevelü” hőháztartás típushoz tartozik, 12\% (7 faj) a „szubmediterrán lomberdo”, 4\% (2 faj) ,tü- és lomblevelü elegyes erdei” faj, $11 \%$ ( 6 faj) pedig indifferens a klímára, ezek többnyire kozmopolita taxonok (pl. Marchantia polymorpha, Ceratodon purpureus, Hypnum cupressiforme; 5. ábra).

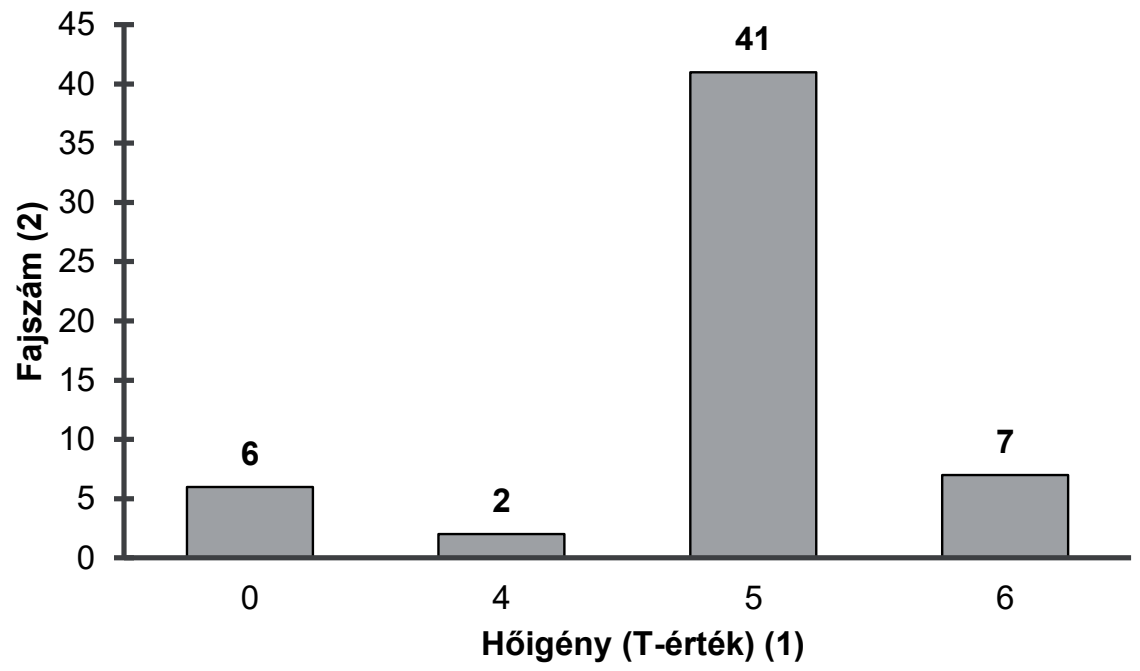

5. ábra. A Budai Arborétum mohafajainak hőigény (T-érték) szerinti eloszlása. 0 = indifferens; $4=$ tü- és lomblevelü elegyes erdő; $5=$ lomberdő; $6=$ szubmediterrán lomberdő.

Fig. 5. Frequency distribution of bryophyte species according to the temperature requirement classes ( $T$-values) in the Buda Arboretum. $0=$ indifferent; $4=$ coniferous and deciduous mixed forest; $5=$ deciduous forest; $6=$ sub-Mediterranean deciduous forest. (1) temperature requirements (T-value); (2) number of species.

A nedvesség igény (W-érték) jóval heterogénebb eloszlást mutat, ezzel együtt a 0-3 indikátorszámú („extrém száraz”, „igen száraz”, „száraz”, „mérsékelten száraz") fajok magas aránya (59\%, 33 faj) jól mutatja a kert száraz klímáját (pl. Grimmia pulvinata, Syntrichia ruralis, Homalothecium sericeum, Frullania dilatata). A 4-5 indikátorszámú, „mérsékelten üde” és „üde” fajok aránya 30\% (17 faj, pl. Amblystegium serpens, Fissidens taxifolius), a fennmaradó 11\% (6 faj) 6, 8, illetve 9 indikátorszámmal a „mérsékelten nedves”, „mérsékelten vizes” és „vizes" kategóriába tartozik (pl. Brachythecium rutabulum, Marchantia polymorpha, Calliergonella cuspidata; 6 . ábra).

$\mathrm{Az}$ aljzat kémhatásához $(\mathrm{pH})$ való alkalmazkodottság (R-érték) alapján a fajok 54\%-a indifferens (30 faj, pl. Bryum bicolor, Hypnum cupressiforme, Tortula muralis), a maradék $46 \%$ pedig bázikus indikációval jellemezhető (26 faj, pl. Dicranella varia, Pseudocrossidium hornschuchianum, Tortella tortuosa; 7. ábra). 


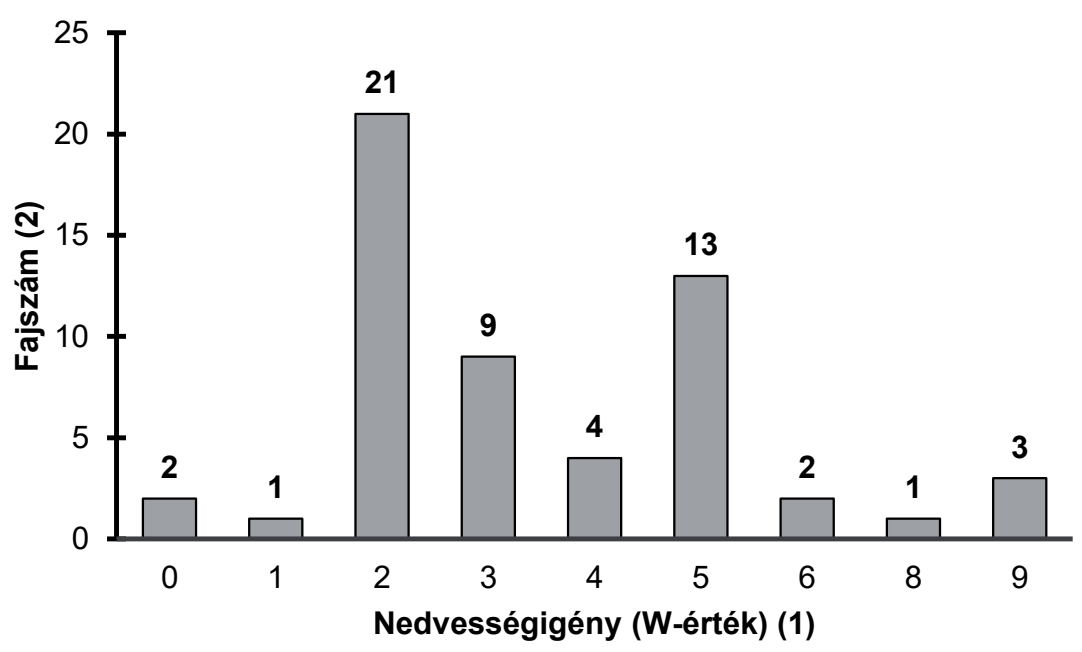

6. ábra. A Budai Arborétum mohafajainak nedvességigény (W-érték) szerinti eloszlása. $0=\mathrm{ex}-$ trém száraz, 1 = igen száraz, 2 = száraz, 3 = mérsékelten száraz, $4=$ mérsékelten üde, $5=$ üde, $6=$ mérsékelten nedves, $8=$ mérsékelten vizes, $9=$ vizes.

Fig. 6. Distribution of the water requirement values (W-values) of the bryophyte flora in the Buda Arboretum. $0=$ extremely dry, $1=$ very dry, $2=$ dry, $3=$ moderately dry, $4=$ moderately mesic, $5=$ mesic, $6=$ moderately damp, $8=$ moderately wet, $9=$ wet. (1) water requirements (W-value); (2) number of species.

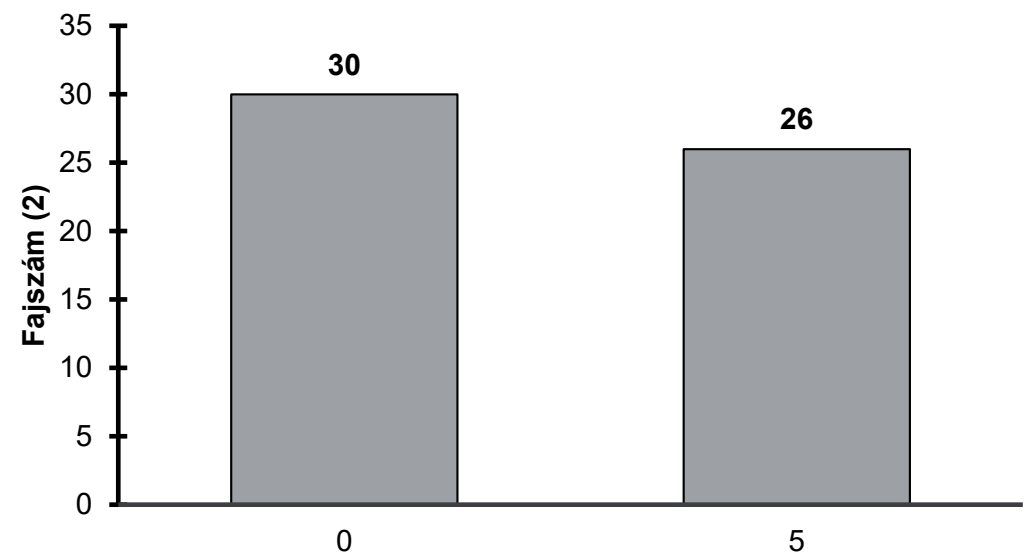

Aljzat kémhatás érték (R-érték) (1)

7. ábra. A Budai Arborétum mohafajainak ajzat kémhatás értékének (R-érték) eloszlása. 0 = indifferens, 5 = bázikus.

Fig. 7. Distribution of the substrate $\mathrm{pH}$ indicator values ( $\mathrm{R}$-values) of the bryophyte flora in the Buda Arboretum. 0 = indifferent, 5 = basic. (1) substrate $\mathrm{pH}$ indicator value (R-value); (2) number of species. 
Életstratégia szempontjából a fajok többsége (64\%, 36 faj) pionír természetü, kolonista (C, pl. Barbula unguiculata, Bryum argenteum, Syntrichia papillosa), 20\%-uk (11 faj) évelö állandó (P, pl. Brachythecium rutabulum, Eurhynchium hians), 9\% (5 faj) hosszú életủ vándorló (LS, pl. Orthotrichum lyellii, Plagiomnium cuspidatum), 3\% (2 faj) rövid életủ vándorló (SL, pl. Pellia endiviifolia), 2-2\% (1-1 faj) pedig ún. átfutó (F, Funaria hygrometrica), illetve egyéves vándorló (AS, Phascum cuspidatum; 8. ábra).

Az epifitonok esetében megfigyelhető, hogy a vékonyabb oldalágakon, fiatalabb fák törzsén, nyílt helyeken a kiszáradástürő fajok vannak jelen többségben (pl. Orhotrichum spp.), míg az idősebb fákon, a vastagabb törzseken inkább a kiszáradásra érzékenyebb fajok élnek ( $\mathrm{pl}$. Syntrichia papillosa). Kivétel az Orthotrichum diaphanum, mely mind fiatal, mind idős fák törzsén, illetve ágain nagy mennyiségben megtelepedett.

A sziklakertekben kizárólag mészkősziklákat találunk, ennek megfelelően ott csak mészkedvelö fajok fordulnak elö, pl. Pseudocrossidium revolutum. Az Alsó Kertben található sziklakertet többet öntözik, mint a felsőt, itt a víztöbblet miatt nem tudnak megjelenni olyan tipikus sziklalakó fajok, mint pl. a Grimmia dissimulata vagy a Syntrichia montana, melyek a felső sziklakertben elöfordulnak. Érdekes élőhelyek alakultak ki a Felső Kert elhanyagolt és kevéssé látogatott részein; a sportcsarnok feletti mindig árnyas betonlépcsőkön pl. igen gaz-

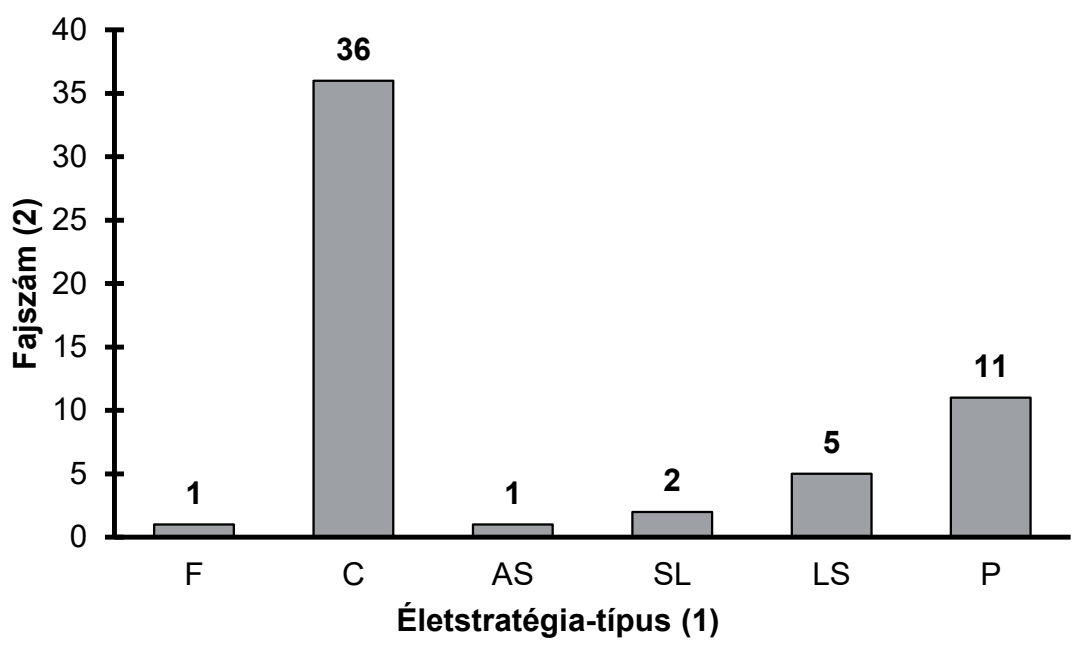

8. ábra. A Budai Arborétum mohafajainak életstratégia-típus eloszlása. $\mathrm{F}=$ átfutó, $\mathrm{C}=$ első megtelepedő, $\mathrm{AS}$ = egyéves vándorló, $\mathrm{SL}$ = rövid életủ vándorló, $\mathrm{LS}=$ hosszú életủ vándorló, $\mathrm{P}=$ évelő állandó.

Fig. 8. Distribution of the life-strategy types of the bryophyte flora in the Buda Arboretum. $\mathrm{F}=$ fugitive, $\mathrm{C}=$ colonist, $\mathrm{AS}=$ annual shuttle, $\mathrm{SL}=$ short lived shuttle, $\mathrm{LS}=$ long-lived shuttle, $\mathrm{P}=$ perennial. (1) life-strategy type; (2) number of species. 
dag és háborítatlan mohaközösségek jöttek létre, csak itt található az Encalypta streptocarpa. Az arborétum egyéb betonépítményei is számos mohafajnak adnak otthont, ezeken az élőhelyeken megjelennek a kevésbé mészkedvelő mohák is, mint pl. a Ceratodon purpureus.

A szennyezettség, a város közelsége és a kertészeti hasznosítás miatt a talaj mohaflórája igen fajszegény. A legtöbb helyen a talaj komoly taposásnak van kitéve, ezeken a helyeken mohákat is alig találunk. Az arborétum kevésbé látogatott részein valamivel érdekesebb összetételü a talajlakó mohaközösség, pl. csak a kollégium feletti területen fordul elő a Calliergonella cuspidata, valamint csak az „F” épület fölötti lezárt részen nő a Marchantia polymorpha, illetve itt található a Dicranella varia egy nagyobb állománya.

Különleges élőhelynek számítanak az üvegházak, melyek a kintitől teljesen eltérő klímával rendelkeznek, talajadottságai is különböznek, az ültetőközegek gyakran savanyúak. Az arborétumban csak üvegházban fordul elö az Amblystegium bumile és a Leptobryum pyriforme.

Érdekes élőhely továbbá az arborétumi tó közvetlen környéke. A környező talaj nedvességtartalma magasabb, mint másutt, a tavat szegélyező sziklák folyamatosan nedvesek. Csak itt fordul elö a Pellia endiviifolia.

A magyarországi gyüjteményes kertek és parkok térképezése során változatos klímájú területeken végeztek mohaflorisztikai kutatásokat az utóbbi évtizedekben. A teljes körű arborétumi és botanikus kerti mohatérképezések alkalmával a különböző szerzők igen eltérő fajszámú és fajösszetételű mohaflórát találtak (1. táblázat).

1. táblázat. Hazai gyűjteményes kertek mohaflorisztikai felméréseinek eredményei.

Table 1. Results of bryofloristical surveys in Hungarian botanical gardens and arboretums; (1) author and year, (2) location, (3) size in hectare, (4) number of species.

\begin{tabular}{|c|c|c|c|}
\hline Szerző (év) (1) & Helyszín (2) & Méret (ha) (3) & Fajszám (4) \\
\hline VAJDA (1954) & Vácrátót & 27 & 102 \\
\hline VAJDA (1968) & Szigliget & 10 & 48 \\
\hline Galambos (1992), SzÜCs (2013) & Zirc & 18 & 79 \\
\hline Szücs (2009) & Agostyán (Tata) & 30 & 37 \\
\hline NÉMETh és PAPP (2016) & Soroksár & 60 & 67 \\
\hline NAGY et al. (2016) & Martonvásár & 70 & 56 \\
\hline SzÜCs et al. (2017a) & Erdőtelek & 3 & 18 \\
\hline $\begin{array}{l}\text { SZÜCS és PÉNZESNÉ KóNYA (2016), } \\
\text { SZÜCs et al. (2017c) }\end{array}$ & Eger & 1 & 46 \\
\hline Szücs (2017) & Sopron & 17 & 78 \\
\hline Szücs et al. (2018) & Gyöngyös & 14 & 65 \\
\hline Rigó et al. (2019) & Budapest & 9 & 56 \\
\hline
\end{tabular}


Figyelembe véve a Budai Arborétum 9 hektáros területét, valamint azt, hogy a kert a fővárosban erős antropogén hatásnak van kitéve, megállapítható, hogy az általunk megtalált 56 mohafajjal (4 májmoha és 52 lombos moha) a Budai Arborétum jelentős mohaflorisztikai értéket képvisel. Az aktuális vörös listás besorolás szerint (PAPP és mtsai 2010) a megtalált fajok jelentős része országosan gyakori, azonban néhány, a vörös listán mérsékelten fenyegetett (near threatened) besorolással szereplő faj (Gymnostomum calcareum, Orthotrichum obtusifolium, Orthotrichum pumilum, Pseudocrossidium revolutum) is elökerült.

\section{Köszönetnyilvánítás}

Köszönettel tartozunk Peter Erzbergernek egyes mohafajok meghatározásában nyújtott segítségéért, valamint értékes szakmai tanácsaiért.

\section{Irodalomjegyzék}

Boros Á. 1915-1971: Florisztikai jegyzetek. Kézirat, Magyar Természettudományi Múzeum, Budapest.

Boros Á. 1953: Magyarország mohái. Akadémiai Kiadó, Budapest, 360 pp.

Erzberger P. (előkészületben): Keys to Hungarian Bryophytes. Test Version. kézirat.

Galambos I. 1992: A zirci arborétum mohaflórája. Folia Musei Historico-Naturalis Bakonyensis 11:29-35.

Hill M. O., Bell N., Brunneman-Nannenga M. A., Brugués M., Cano M. J., Enroth J., Flatberg K. I., Frahm J.-P., Gallego M. T., Garilleti R., Guerra J., Hedenäs L., Holyoak D. T., Hyvönen J., Ignatov M. S., Lara F., Mazimpaka V., Munoz J., SÖDERSTRÖM L. 2006: An annotated checklist of mosses of Europe and Macaronesia. Journal of Bryology 28: 198-267. https://doi.org/10.1179/174328206X119998

IGMÁNDY J. 1949: Adatok Sopron mohaflórájához. Erdészeti kísérletek 49(1-4):164-167.

NAGy Z., MAJLÁth I., MolnÁr M., ErZberger P. 2016: A martonvásári kastélypark mohaflórája. Kitaibelia 21(2): 198-206. https://doi.org/10.17542/kit.21.198

NÉMETH Cs., PAPP B. 2016: Mohák a Soroksári Botanikus Kertben. In: HöHn M., PAPP V. (szerk.): Biodiverzitás a Soroksári Botanikus Kertben. Magyar Biodiverzitás-kutató Társaság és SZIE Kertészettudományi Kar, Soroksári Botanikus Kert, Budapest, pp. 111-149.

ORbÁn S. 1984: A magyarországi mohák stratégiái és T, W, Rértékei. Acta Academiae Paedagogicae Agriensis. Nova series 17: 755-765.

ORBÁN S., VAJDA L. 1983: Magyarország mohaflórájának kézikönyve. Akadémiai Kiadó, Budapest, $518 \mathrm{pp}$.

Papp B., ErZberger P., Ódor P., Hock Zs., Szövényi P., Szurdoki E., Tóth Z. 2010: Updated checklist and redlist of Hungarian bryophytes. Studia botanica hungarica 41:31-59.

Pócs T., Van Zanten B. O., Erzberger P. 2008: Entodon concinnus (De Not.) Paris. In: Blockeel T. L. (szerk.): New national and regional bryophyte records, 18. Journal of Bryology 30: 163. https://doi.org/10.1179/174328208X282463

Schmidt G. (szerk.) 2013: A Budapesti Corvinus Egyetem Budai Arborétuma. Budapesti Corvinus Egyetem, Kertészettudományi Kar, Dísznövénytermesztési és Dendrológiai Tanszék, Budapest, $56 \mathrm{pp}$. 
Rigó A. et al.

Sмiтн A. J. E. 2004: The mossflora of Britain and Ireland. Cambridge University Press, Cambridge, $1012 \mathrm{pp}$.

SzŰCs P. 2009: Mohaadatok az Agostyáni Arborétumból. Komárom-Esztergom Megyei Múzeumok Közleményei 15: 159-164.

SzŰcs P. 2013: Kiegészítések a Zirci Arborétum mohaflórájához. A Bakonyi Természettudományi Múzeum Közleményei 30: 47-54.

SzÜcs P. 2017: Bryophyte flora of the Botanic Garden of the University of Sopron (W Hungary). Studia botanica hungarica 48(1): 77-88. https://doi.org/10.17110/StudBot.2017.48.1.77

SzŰCs P., BARANYi G., Fintha G. 2018: The bryophyte flora of the park of Mátrai Gyógyintézet sanatorium (NE Hungary). Acta Biologica Plantarum Agriensis 6: 123-132. https://doi.org/10.21406/abpa.2018.6.123

SzÜCs P., BARANYI G., Zöllei T. 2017a: Az Erdőtelki Arborétum mohaflorisztikai vizsgálatának előzetes eredményei. Acta Academiae Agriensis, Sectio Biologicae, Nova series 44(1): 121-126.

SzÜcs P., LóTH H. 2008: Almásfüzitő antropogén élőhelyeinek mohaflórája. Komárom-Esztergom Megyei Múzeumok Közleményei 13-14: 399-423.

SzŰ́cs P., PÉnzesné Kónya E. 2016: Mohaadatok az Eszterházy Károly Főiskola Botanikus Kertjéből (Eger). Acta Academiae Agriensis, Sectio Biologicae, Nova series 43(1): 53-57.

SZÜCs P., PÉnZESnÉ KónYA E., Hofmann T. 2017b: The bryophyte flora of the village of Almásfüzitő, a former industrial settlement in NW-Hungary. Cryptogamie, Bryologie 38(2): 153170. https://doi.org/10.7872/cryb/v38.iss2.2017.153

SzǗcs P., TÁborská J., Baranyi G., PÉNZes-KónYa E. 2017c: Short-term changes in the bryophyte flora in the botanical garden of Eszterházy Károly University (Eger, NE Hungary). Acta Biologica Plantarum Agriensis 5(2): 52-60. https://doi.org/10.21406/abpa.2017.5.2.52

VAJDA L. 1954: A Vácrátóti Botanikai Kutatóintézet természetvédelmi parkjának mohái. Botanikai Közlemények 45: 63-66.

VAJDA L. 1968: A Szigligeti Arborétum monográfiája, V. A Szigligeti Arborétum mohái. A Veszprém megyei Múzeumok Közleményei 7: 237-240.

ZsóLyom D., Szücs P. 2018: Balaton település (Heves megye) mohaflórája. Botanikai Közlemények 105(2): 231-242. https://doi.org/10.17716/BotKozlem.2018.105.2.231

\title{
Bryophyte flora of the Buda Arboretum (Budapest, Hungary)
}

\author{
A. RIGÓ ${ }^{1}$, A. KOVÁCS ${ }^{2}$, Cs. NÉMETH ${ }^{3}$ \\ ${ }^{1}$ Department of Botany, Hungarian Natural History Museum, \\ H-1087 Budapest, Könyves Kálmán krt.40, Hungary; rigo.attila@nhmus.hu \\ ${ }^{2}$ Faculty of Horticultural Science, Szent István University, \\ H-1118 Budapest, Villányi út 29-43, Hungary \\ ${ }^{3}$ GINOP Sustainable Ecosystems Group, MTA Centre for Ecological Research, \\ H-8237 Tihany, Klebelsberg Kuno út 3, Hungary
}

Accepted: 29 May 2019

Key words: arboretums and botanical gardens, bryophyte flora, ecological indexes, life strategies. 
We completed a bryofloristical study in the whole territory of the Buda Arboretum (Budapest, Hungary). As a result of our survey, 56 bryophyte species were found altogether. The majority of the species are frequent in Hungary. Four of them (Gymnostomum calcareum, Orthotrichum obtusifolium, Orthotrichum pumilum, Pseudocrossidium revolutum) however, are classified as Near Threatened species according to the Red List of Bryophytes. The most abundant epiphytic bryophyte is Orthotrichum diaphanum, the most frequent one on limestone rocks is Schistidium crassipilum, and that on concrete is Amblystegium serpens. Eurhynchium hians has the greatest coverage on soil in the arboretum. Near three quarters of the bryophytes of the arboretum are in the "deciduous forest" category based on temperature requirement classes (T-values). Considering the water requirement classes (W-values), two thirds of the encountered bryophytes belong to one of the groups of "extremely dry", "very dry", "dry" and "moderately dry". This is a bioindication of the dry climate of the arboretum. Regarding the substrate $\mathrm{pH}$ tolerance classes (R-values), nearly half of the bryophytes are "indifferent", the other half is "basifrequent". Two thirds of the bryophyte species in the arboretum are colonists, while the rest either perennials, long-lived shuttles, short-lived shuttles, fugitives or annual shuttles according to life-strategy types. 